\title{
Franz Brentano's theory of JUdgMent (1889): A CRITIQUE OF ARISTOTLE'S CORRESPONDENCE THEORY OF TRUTH
}

\author{
Evandro Oliveira de Brito ${ }^{1}$
}

\begin{abstract}
The purpose of this paper is to discuss the concept of truth formulated by Franz Brentano in 1889. As a textual basis, I take Brentano's communication, presented to the philosophical community of Vienna in March 1889, entitled "On the concept of truth" (Über den Begriff der Wahrheit), and I provide a systematic exposition of Brentano's analysis of the problems surrounding the interpretation of the Aristotelian concept of truth as correspondence. My analysis explains how Brentano reinterpreted the Aristotelian concept of truth as correspondence within the conceptual framework of his descriptive psychology.
\end{abstract}

KEYwords: Franz Brentano. Intentionality. Truth. Correspondence. Descriptive psychology.

\section{AN INTERPRETATIVE KEY FOR PRESENTING BRENTANO's CONCEPT OF TRUTH}

In order to present not only the analysis, problem, and solution, but, in particular, the concept of truth as formulated by Franz Brentano, I will follow his footsteps in the systematic exposition of the Aristotelian concept of truth as correspondence. Thus, I will indicate the fundamental aspects of Brentano's philosophy of mind, as formulated in the context of his communication presented to the philosophical community of Vienna in March 1889. This communication was entitled "On the concept of truth" (Über den Begriff der Wahrheit). It was published as the first chapter of the work The True and the Evident (Wahrheit und Evidenz: Erkenntnistheoretische Abhandlugen und Briefe).

The problem of truth that I analyze here assumes-in addition to Porta's (2002) interpretive analysis about the equivocity problem of being-

\footnotetext{
${ }^{1}$ Philosophy Department, Universidade Estadual do Centro Oeste (UNICENTRO), Guarapuava, PR - Brazil. Fundação Aruacária/CAPES. E-mail: evandro@unicentro.br
}

http://dx.doi.org/10.1590/0101-3173.2018.v41n3.03.p39 
the results of some analyses that I have recently published in two papers, which presented what Brentano defined as a conceptual framework (Gedankenkreise) of his descriptive psychology. In one of these papers (BRITO, 2012a), I analyzed some of Chisholm's considerations about changes present in the Brentanian definition of psychical phenomena, as presented in his works from 1889-1891, which comprise the book Descriptive psychology. In addition, I introduced Chisholm's thesis, which points out changes in the 'doctrine of intentional in-existence of an object', as presented in the book Psychology from an empirical standpoint. More specifically, I described how Chisholm found these changes in the Brentanian description of psychical phenomena and attributed them to the abandonment of the Thomistic-Aristotelian ontology that underlies the doctrine of intentional in-existence of an object. Chisholm's analysis also presents a new definition of psychical phenomena, as formulated by Brentano in the work Descriptive psychology. In order to demonstrate this new definition, I highlighted how the new epistemological foundation pointed out by Chisholm's thesis describes the intentional relation of all psychical acts. Finally, I highlighted the virtue of Chisholm's thesis in its interpretation of the reception of Descartes in the work Descriptive psychology and its new classification of psychical phenomena.

My second paper (BRITO, 2012b) analyzed the manuscript Psychognosy (Psychognosie); this is the title of the readings presented by Franz Brentano at the University of Vienna in 1890. Specifically, I addressed the new description of intentional psychical acts, as explained by Brentano, based on the analysis of consciousness developed in this manuscript. Thus, my research showed how Brentano described the unity of consciousness as the whole, distinguished in its parts, which was the object of Psychognosy. In addition, the fundamental point of my research demonstrated that, by assuming the interpretation introduced by Chisholm (1969), the new description of psychical acts (as a relation between the parts of consciousness) introduces some fundamental changes to the Brentanian theory of intentionality. It describes two distinguishable types of intentional relations which characterize, on the one hand, the intentional acts of presentation and, on the other hand, the intentional acts of judgment.

Specifically, my analysis showed that Brentano (1995, p. 27) describes presentation as the class of "the parts of intentional pairs of correlates" and, based on this description, the presentation is an intentional act directed toward its respective correlate, characterized as an immanent object. Moreover, I showed that judgment is described as the class of "merely distinctional parts 
of the psychical Diploseenergie [primary and secondary psychical relation]" (BRENTANO, 1995, p. 27) and, based on this description, the judgment is an intentional act directed toward a presentation. Thus, I highlighted the fact that judgment is directed toward presentation as a whole and presentation is directed toward the immanent object. Therefore, as psychical Diploseenergie, presentation (as a whole_-and not the immanent object of presentation) is the primary object of judgment, and judgment itself is the secondary object.

Therefore, the description of intentional activity of the act of judging as the class of merely distinctional parts of the primary and secondary psychical relation (Diploseenergie) is the Brentanian fundamental assumption for the analysis of the concept of truth as correspondence. Thus, I move onto the textual analysis without losing sight of this assumption.

\section{FranZ BRENTANO'S CONCEPT OF TRUTH AND RELATED PROBLEMS}

In the work On the concept of truth (Über den Begriff der Wahrheit), Brentano's analysis returns to the classic Aristotelian definition of truth understood as adaequatio rei et intellectus. However, opposed to the traditional interpretation of the Aristotelian concept of truth as correspondence, this analysis is guided by definitions, distinctions, and classifications made by Brentano himself in his doctoral thesis, in which he developed a theory about the multiple meanings of being, according to Aristotle. Thus, as he had done in 1874 based on Aristotelian assumptions, Brentano consistently sustained, in 1889 , that true and false (in themselves) could be found in all judgments, and could be deemed either affirmative or negative. Brentano's analysis (1975, p. 22-23) was timely and he directly pointed to the main Aristotelian definition of truth by mentioning and interpreting the following passage of Metaphysics:

The preceding investigation has shown that Aristotle uses the words "true" and "false" in several senses; hence it will now be important to determine in which of these meanings it is employed when he deals with being in the sense of being true and non-being in the sense of being false. It does not seem difficult to decide this question since, in Met. VI. 428 Aristotle explains himself with a clarity that leaves nothing to be desired by saying that the on hos alethes and the me on hos pseudos occur only in judgments, either affirmative or negative. "Being as the true and non-being as the false are found in combination and separation, and both together in the division into contradictories, since the truth has affirmation when there is combination, and negation when there is separation, while the false in each case has the contradictory opposite.... For the true and the 
false are not in things...but in the understanding, and not even in the understanding where simple concepts are concerned." Obviously, it is the judgment which is here called true and false, hence to be or not to be.

Formulating his own meaning as he interpreted Aristotle's theory, Brentano used the delimitation of judgment as a place of truth and falsity as a touchstone for his description of judgment as a psychical act of attribution of true and false. As we shall see, this description was characterized by the fact that judgment, analyzed from the perspective of Brentano's Descriptive psychology from 1889, had a specific structure. In addition, this structure consisted of existential predication of a presentation (act of presenting anything), be it simple [(A) is] or compound [(A and B) is]. Thus, Brentano (1975, p. 23) explained and exemplified the act of judgment as follows:

Judgment itself is the subject to which being belongs as a predicate. Hence the being of which he here speaks is not the copula which connects subject and predicate in the sentence itself, especially since a negative judgment, too, is said to have being, and an affirmative one non-being. Rather we are concerned with a being which is predicated of the entire, fully articulated judgment. This may be clarified through an example. Let us suppose somebody wanted to demonstrate to someone else that the sum of the angles in a triangle is equal to two right angles, and that he requires as a starting point of the proof the assumption that the exterior angles are equal to the opposing interior angles. The question now is whether this is or is not [the case], i.e., is it true or is it false? It is! i.e., it is true.

It is worth mentioning that Brentano developed his analysis of the Aristotelian concept of truth by taking as a basis the foundations of his description of psychical phenomena to judge, defined in 1889 as merely distinctional parts of the psychical Diploseenergie [primary and secondary psychical relation]. In this context, judgment was described as a psychical act intentionally directed toward presentation and, in turn, presentation was described as an intentional psychical act directed toward an immanent object. Because of these theoretical orientations, Brentano held that the correct definition of truth could be established by analyzing the Aristotelian answer to the question: "When is a judgement false and when is it true?" As described in the following quote, Aristotle's answer to that question demarcates the starting point of the Brentanian analysis:

His answer is this: a judgment is true if the one who makes the judgment is related to things in a way which corresponds to them, and a judgment is 
false if the one who makes the judgment is related to things in a way which is contrary to them. "He who thinks the separated to be separated and the combined to be combined has the truth, while he whose thought is in a state contrary to that of the objects is in error." (Met. IX, 10, 1051b3). And so it was that truth was explicated as being a kind of agreement or correspondence obtaining between things and judgment. (BRENTANO, 2009, p. 4)

Having thusly explained the Aristotelian definition, Brentano recognized the need to dispel the problems involved in the notion of "correspondence". Let us consider the first such problem.

Brentano agreed that it was necessary to clarify the Aristotelian way of understanding the connection of what is combined and the separation of what is separated. In other words, he said that this was explicit in the following statements by Aristotle:

Aristotle states in the De Interpretatione that judgment is a combination

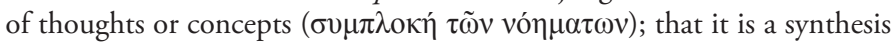
( $\sigma v ́ v \vartheta \varepsilon \sigma ı \varsigma)$. He says that the synthesis consists either in taking one thing to be combined with another, thus forming a unity, or else in taking one thing to be separated or cut off from another. One judges truly when one takes as combined things that really are combined, or when one takes as separated things that really are cut off from one another. One judges falsely, on the other hand, if one judges in a way that is contrary to the way in which the things are related. (BRENTANO, 2009, p. 11)

According to the Brentanian analysis, this definition of truth incurred ambiguity because it supported the interpretation proposed by "[...] those who think there is a relation of identity, or of sameness, or of similarity, between a true thought and a thing" (BRENTANO, 2009, p. 14).

Guided by the theory of judgment based on the philosophy of mind, developed by 1889 , the Brentanian analysis deemed as completely false the proposition that truth is the correspondence of judgment and things. Brentano (2009, p. 13-14) asserted that "it must be given an interpretation quite different from the one offered by those who think there is a relation of identity, or of sameness, or of similarity, between a true thought and a thing." Indeed, he intended to support the thesis that the truth is the correlation between judgment and anything, but that anything is not a real thing. Thus, by means of a disjunctive syllogism, the classical contradictions were shown 
to involve the possibility of agreement among judgments and real things. Such contradictions involved both cases of negative judgments and cases of affirmative judgments. In order to demonstrate the problem, I will discuss, separately, both of these classes of impossibilities which Brentano sought to eliminate from his theory of truth. I will start with the former.

As described in the following quote, Brentano exemplified the impossibility of correspondence between negative judgments and things based on the fact that what should be the correspondent of true negative judgment does not exist as a real thing_or, in his terms, is an existing non-real.

The difficulty is especially clear in the case of simple denial. If the truth of "There is no dragon" were to reside in a correspondence between my judgment and an object, what would the object be? Certainly not the dragon, since there isn't any dragon. Nor is there any other real thing which could count as the corresponding reality. (BRENTANO, 2009, p. 13)

As Brentano argues, the foregoing argument proposes a refutation of the traditional interpretation of the notion of correspondence of a judgment to something real, based on the fact that true negative judgments are such, regardless of the reality of what is being affirmed. This means that Brentano is already analyzing the correspondence of negative judgments, based on the criteria of his descriptive psychology. In other words, he is simply assuming the reality of the act of presenting anything, rather than the reality of what is presented (whose existence can be real or non-real). As highlighted in the citation that follows, the same is true for the negative judgment of existence.

A similar situation holds when, instead of denying a thing simply, the judgment denies it only as being a real determination of some other object. Suppose I say, "Some man is not black". What is required for the truth of the statement is, not that there is black separated from the man, but rather that on the man. There is an absence or privation of black. This absence, this non-black, is clearly not an object; thus again there is no object given in reality which corresponds to my judgment. It is quite obvious, therefore, that in the case of every true negative judgment-and unmistakably so when the judgment is simple - the correspondence which is supposed to hold between true judgments and reality is not to be found. (BRENTANO, 2009, p. 13)

Having discussed the first impossibility of correspondence, I will move on to the second class of contradiction which involves the impossibility of 
correspondence between judgments and real things. Also, according to Brentano, in addition to true negative judgments, true affirmative judgments also explain the impossibility of correspondence between a judgment and a real thing. As described in the following quotation, this impossibility becomes evident when anything that should be the correspondent of this true judgment does not necessarily exist as a real thing; specifically, when it is a collection of things, parts of it, limits of such a thing, anything in the future or in the past, etc. Therefore, due to this non-existence of things, which necessarily correspond to the affirmative true judgments, Brentano (2009, p. 13) concluded that the traditional interpretation of the concept of adaequatio rei et intellectus was completely annihilated. Let us consider his argument.

The other case, which seems to lead to a similar result, may be seen by noting the area in which the affirmative function is exercised. We find, of course, that the affirmative judgment often does apply to things; but we also find-I shall make the point clear with examples—-that it often applies to objects to which the word "thing" should not be applied at all. Now whenever a true affirmative judgment does apply to a thing-whether the judgment be one which simply accepts or affirms the thing or one which attributes to it some further determination - we can indicate a correspondence between the judgment and the thing. But how are we to do this when the judgment does not apply to a thing? A true affirmative judgment may, of course, apply to a single thing. But it may also apply to a collection of things, or to a part of a thing, or to the limit or boundary of a thing, and the like-all these latter being objects which are not themselves things. Or, if there were someone who ventured to say of such objects that they are really things, would he want to say the same of an object that I know to have perished a long time ago, or to exist in the distant future? Here we are not dealing with any thing that exists external to me. And still more! What if I affirm the absence or the lack of a thing? Will it then be said that this absence, this lack of a thing, is itself a thing? Or if I were to say that there is a certain impossibility, or that there are certain eternal truths (the laws of mathematics, for example), would it then be supposed that there are eternal things, perhaps similar to Platonic ideas, which exist in, or outside of, the world? Certainly not! The whole idea of the adaequatio rei et intellectus seems to go completely to pieces.

Based on the exposition of such impossibilities, the Brentanian analysis inferred the need for a new interpretation of what would become known as the Aristotelian conception of concordance between judgment and any thing. Having presented the Brentanian point of departure, I will now return to the 
exposition of the philosophical problem of truth, to which Brentano presents a solution within his philosophy of mind.

\section{THE CARTESIAN ORIENTATION TOWARD DISSOLVING MISCONCEPTIONS CONCERNING THE CONCEPT OF TRUTH}

As explained by the Brentanian analysis, the guiding philosophical problem of the concept of truth was introduced into the history of philosophy by the sophist Gorgias. Taking this historical-philosophical fact into account, Brentano's argument considered the classic problematization, as presented by Gorgias, to be a straw man. In his analysis of the pre-Socratic and sophistic arguments, Gorgias was the first to point out the problematic consequences of the notion of truth as correspondence. Brentano (2009, p. 5) summarizes the criticism of Gorgias of the notion of truth as correspondence as follows:

We have Gorgias denying that anything real can be known, and then adding that, even if there were anything that could be known, it would be impossible to communicate the knowledge from one person to another. There is nothing which corresponds completely to anything other than itself. What is external to me is not in me, and what is and remains in me does not pass over into anyone else. Thus truth, as well as the communication of truth, is impossible. If any of our thoughts can be said to be true, then, according to Gorgias, everything else can be said to be true. For every thought is identical with itself as well as different from all other thoughts. But that every thought should be called true, even when I think of a chariot race on the sea, is an absurdity.

There is no doubt that the thesis of Gorgias needs a more rigorous analysis, because it characterizes the fundamental problem of the theory of knowledge. However, Brentano's purpose was to describe how the problem of truth posed by Gorgias could be dissolved by the philosophy of mind. Thus, Brentano's question is: how? The answer is by the application of the criteria of analysis which were found in the description of relation between the parties and the whole of consciousness; in other words, through the relations that support the theoretical foundations of his descriptive psychology.

The Brentanian analysis explains that the solution to the problem raised by the sophist Gorgias "[...] stems from a failure to recognize the distinction, which Descartes had described as the distinction between formal and objective reality" (BRENTANO, 2009, p. 10). However, with regard to this Cartesian 
solution, Brentano (2009, p. 10) said that "[it] had been brought fully to light long before by Aristotle, who used it in overcoming the absurdities and sophistries of Parmenides, Gorgias, Protagoras, and others". As mentioned in the following quote, the solution to the problem is to distinguish, in a psychical act of belief, the constituents of formal reality and the elements of objective reality:

If I believe something, then this belief is "formally" in me. When I later recall the belief, then, according to Descartes' way of speaking, the value is "objectively" in me. In each case the same particular act of belief is involved; but in the one case it is my act itself and in the other it is only the immanent object of my remembering. (BRENTANO, 2009, p. 10)

Brentano's view expressed in the quote above assumes the following interpretations in the contexts of formal reality and objective reality: in the context of formal reality, the psychical act of believing formally consists of belief. In this case, the belief would be the psychical act in its full operation (or, in Brentano's terms, a judgment). Thus characterized as judgment, the psychical act of believing presupposes a psychical act of presenting anything. The following propositions illustrate Brentano's analysis. The proposition "I think I hear that sound" should be reduced to the psychical form, "It is true, I hear that sound." Also, these two modes are described as existential predications of the type [(A) is] because "A" describes "I hear that sound" and "is" describes the act of judgment that assigns the affirmative mode of existence to proposition "A". Similarly, the proposition "I do not think I hear that sound" should be reduced to the psychical form, "It is not true, I hear that sound." These two modes are also described as existential predications of the type [(A) is not] because "A" describes "I hear that sound" and "is not" describes the act of judgment that assigns the negative mode of existence to proposition "A".

In the context of objective reality, the psychic act of remembering objectively consists of belief. The question is, how? In this case, the belief is the immanent object to the psychical act of remembering, characterized as a presentation. I will draw on previous proposals to illustrate the point analyzed by Brentano. Taken as basic psychical acts, the act of hearing anything and the act of remembering anything are presentations; that is, they are acts of presenting immanent object correlates. In the examples presented, the correlate of the act of listening is "the sound heard" and the correlate of the act of 
remembering is "the act of having believed I heard something". Therefore, to Brentano, an act of the second type (judgment as belief) came to be conceived as a distinguishable part of an act of type one (memory, as presenting "a belief in anything"). Consider the details of that distinction when applied to the criteria of analysis found in the description of relation between the parties and the whole of consciousness; in other words, when applied to the relations that support the theoretical foundations of his descriptive psychology.

In the case of the formal reality of the belief, the act of judging positively (to believe) includes a distinction between the primary object and secondary object. On the one hand, the act of presenting as the primary object is directed to the immanent object; the latter constitutes the presented correlate. On the other hand, the secondary object involves the affirmative act of judging (to believe) by assigning reality (the being-real) to the primary object (act of presenting the immanent object). However, in the case of objective reality of belief, the act of remembering anything is simply an act of presenting and, therefore, is directed toward a presented object. Belief is, thus, this immanent presented object.

If I apply the distinctions proposed by Brentano's criteria of analysis, I can say that, as formal reality, belief is the secondary objective activity of the act of judging; as objective reality, belief is the correlate in the act of rememberingthat is, simply the immanent object given in that intentional relation.

Brentano supports his thesis about the truth as correspondence in two ways: a) his criteria for description of the relation between parts and the whole of consciousness; b) a distinction between the two Cartesian modes of psychical activity (formal reality and objective reality). Brentano's thesis claims that only the description of formal reality could explain, in an evident way, correspondence which characterizes the knowledge of activity. Judgments, structured by primary and secondary psychical relations (Diploseenergie), rather than presentations constituted by objective realities, explain the notion of truth as correspondence in the Brentanian theory of knowledge. According to Brentano, that is the main argument for rejecting the notion of truth in the class of presentations. Thus, there is no way to conceive presentations as knowledge.

It should be noted that this distinction, structured by primary and secondary psychical relations (Diploseenergie), refers not only to the psychical activity of the second class (judgments), but also to the psychical activities of the third class (feelings of love or hate). As Brentano (2009, p. 10) points 
out in the following quote, this should be the locus of the whole theory of knowledge and even the theory of moral knowledge:

....similarly for every other mental function — volition, desire, aversion, and the like. Every mental act, in itself given formally, has its immanent object which, in Descartes' terms, is given objectively. To avoid misunderstandings, we might express this better by saying that the immanent object is given intentionally. It is obvious that no contradiction is involved in saying that something is in me intentionally but not formally, or vice versa, a fact that can be illustrated by the example of remembering, and by thousands of others. A mistake on this point would be a relapse into the crudest stages of the development of the theory of knowledge.

The foregoing arguments suffice to allow me to move on to present the psychical structure used by Brentano to interpret the Aristotelian notion of truth as correspondence.

\section{BRENTANO'S INTERPRETATION: THE EVIDENCE OF JUDGMENT AND THE CONCEPT OF TRUTH}

Let us move on, then, to Brentano's interpretation, taken in light of the criteria of analysis of the work Descriptive psychology. Here is what he said:

Following Aristotle's statement that a judgment is true if it takes as combined what is combined, and so on, we can say: a judgment is true if it asserts of some object that is, that the object is, or if it asserts of some object that is not, that the object is not-and a judgment is false if it contradicts that which is, or that which is not. (BRENTANO, 2009, p. 14)

The above quote explains the relation between truth and being. Before I address this point, it is interesting to note the assumptions of the Brentanian analysis. Brentano supports the Aristotelian theory that the true and the false, taken in the proper sense, are in judgment; however, according to his analysis, this means that the judgment is the existential predication of presentation, be it simple [(A) is] or compound [(A and B) is]. Therefore, the Brentanian analysis needs to define the epistemological status of this mode of being characterized by existential predication.

Brentano explored the limits of his own doctoral thesis and took 
advantage of the theory of multiple meanings, which refers to being able to distinguish between reality and existence. Thus, in 1889, the constituent parts of a psychical act of judgment were also distinguished on the basis of multiple senses of being, which characterize the most basic distinguishable components. On the one hand, the correlate of the act in the primary psychical relation exists or does not exist. In this case, as a basic intentional relation, the presentation is referred to as the correlate which is anything existing but also non-existing. On the other hand, the constituent act of secondary psychical relation is the mode of reality assignment or reality denial. In this case, as a psychical activity, judgment is real in the positive and negative senses. This reality (Wirklichkeit) is the activity of consciousness itself. As a complex intentional relation (Diploseenergie), judgment addresses (and value) positively or negatively the correlate presentation of anything existing or non-existing. Although it is a relatively simple shift, Brentano $(2009$, p. 16) himself acknowledged that the philosophical tradition did not realize the advantages of this distinction:

And finally we shall not be tempted, as so many have been, to confuse the concept of a thing with the concept of an existent. It is a few thousand years since Aristotle investigated the manifold senses of being; it is regrettable that even today there are so many who have not learned from his investigation.

This epistemological reorientation assumed by Brentano inside Aristotelian and Cartesian thought has another implication. It establishes the criteria that support the four fundamental consequences of the definition of truth as correspondence. Let us see how this happened.

First, as stated in the following quotation, that criterion allowed Brentano to recognize the field covered by judgment as unlimited. In other words, every judgment is based on a presentation which is characterized as a primary psychical relation, because all judgment is characterized as a secondary psychical relation. Thus, any presentation could be part of the judgment field of activity. Now, this meant that one could judge as true or false a presentation which assumed anything (existing) to be a correlate of the act of presenting, but one could also judge as true or false a presentation that assumed "nonexistence" as a correlate of the act of presenting. Why was this possible in 1889 ? It was possible because the psychical phenomenon of judgment was described as an assignment of reality (being real or being non-real) to the psychical activity of presenting. Thus, Brentano (2009, p. 14) said: 
The area to which our judgments may be applied is unlimited, and the content of judgment may be as we like. But our judgment always pertains to some entity or other. And what does "entity" signify? It is a term that can be applied to God or to the world, to anything whatever, and to any non-thing.

Secondly, the mode of intentional reference of judgment, while directed toward presentation, explains one bipolarized structure: affirmative and negative. This meant, as Brentano (2009, p. 14) expressed, that "[...] this limitless area can be divided into two parts": affirmative judgment and negative judgment. Moreover, this "[...] opposition between the affirmative and the negative judgment implies, as we know, that in any given case one, and only one, of the two modes of judging is appropriate and that the other is inappropriate" (BRENTANO, 2009, p. 14). Also, according to Brentano (2009, p.14), "[...] this fact is ordinarily expressed by saying that, of two contradictory judgments, one and only one is true and the other false".

The third factor concerns the descriptions of the affirmative domain of judgment, while assigning (being) real to the presentation, and the descriptions of the negative domain, while assigning (being) non-real to the presentation. As part of the psychical whole, the (being) real constituent of the activity of judging is related in some way to the existing; i.e., the correlate of the constituent act of presenting. This relation, as emphasized by Brentano (2009, p. 14) below, is the first indication of harmony or correspondence between the parts of the psychical act:

Let us say that the area to which affirmative judgement is appropriate is the area of the existent, a concept to be sharply distinguished from that of thing; and that the area to which the negative judgement is appropriate is the area of the non-existent.

Brentano then took what was explained in these three points to define the notion of truth as correspondence or agreement. His analysis found that the classic Aristotelian definition should recognize that the truth is the correct assignment of reality (being real) and unreality (being non-real). In this case, the contribution of the philosophy of mind is the possibility of describing the correctness of this act of judging. 


\section{The TRUTH AS CORRESPONDENCE}

The truth is a judgment, as Brentano reminds us constantly in his references to Aristotelian arguments. This argument must be considered, however, in the following sense. The psychical activity of judgment is the intentional relation structured as primary and secondary psychical relations (Diploseenergie). Thus, the psychical act of judging is the secondary activity which ascribes reality (being real) or unreality (being non-real) to the primary psychical relation, called the act of presenting an immanent object (existing or non-existent); i.e., the presentation. Therefore, this act makes the fundamental point of the theory of knowledge explicit; specifically, the fact that the correspondence and agreement could not be identical or similar, but should be conceived as harmony, relevance, or correspondence. This harmony would occur between the activity which assigns reality or unreality (i.e., secondary psychical relation directed toward the primary psychical relation) and the activity of presenting the existing or the non-existing (primary psychical relation, which is called the act of presenting an immanent object, be it anything or "any non-thing"). Let us consider these two fundamental characteristics which make the notion of truth explicit.

First, harmony or correspondence of a true judgment, described by Brentano as fairness, can be explained from both affirmative and negative judgment domains. In other words, every description of judgment in the affirmative domain (where the valuation of truth occurs) shows that the truth is explicit in two areas. On the other hand, the truth is explicit in the correct assignment of unreality (being non-real) to the presentation (when it is a reference to "any non-thing" - the non-existent). In addition, and in a contrary way, any description of the negative domain of judgment (which occurs with an evaluation of false) shows that the false is also explicit in two areas. On the one hand, the false is explicit in the incorrect attribution of reality (being real) to the presentation (when it is a reference to "any non-thing"-the non-existent). On the other hand, the false is explicit in the incorrect assignment of unreality (being non-real) to the presentation (when it is a reference to anything - the existent). Thus, the theoretical efforts of Brentano (2009, p. 14) became understandable, as described in the next quote, when he redefined the notion of correspondence and harmony or agreement:

And this is all there is to the correspondence of true judgment and object about which we have heard so much. To correspond does not mean to be the same or to be similar; but it does mean to be adequate, to fit, to be in agreement with, to be in harmony with, or whatever equivalent expressions one may choose to apply. 
In these terms, therefore, Brentano has defined the notion of truth as the notion originating in the correct psychical attribution of reality (being real) and unreal (being non-real). This can be described as the correctness between two real elements (zwei wirklichen Elemente): a psychical element (the judgment activity) and also another psychical element (the presentation activity).

\section{Conclusion}

As part of an unfinished project in 1889, Brentano's definition of truth has taken a central position in his philosophy of mind. Alongside the problems arising from the basis of the notion of intentional relations, problems related to the truth of evident judgments and to evidence of correct preference assumed central roles in his analysis around 1889.

From 1905 onwards, Brentano proposed a radical overhaul of his project of the philosophy of mind. This radical turn, called reism, is characterized by the phase in which Brentano described the concrete or individual mode as the exclusive mode of the existence of things. However, this was not a pure and simple abandonment of his theory of intentional relation, with its implications for the concept of evident truth and the concept of correct moral preference. On the contrary, such a turn underscored the radicalization of his theory of intentional relation in order to ensure evidence of true knowledge and correct moral preference.

Thus, the analysis set out here is a fundamental step in understanding the final phase of Brentanian thought. For this reason, it is also relevant to analyze Brentano's interpretation of the Aristotelian concept of truth as correspondence and its reworking based on the description of psychical activity of judgment, as an original source of knowledge of what is true and false.

BRITO, E. O. A teoria do juízo de Franz Brentano (1889): uma crítica da teoria aristotélica da verdade como correspondência. Trans/form/ação, Marília, v. 41, n. 3, p. 39-56, Jul./ Set., 2018. 
Resumo: O objetivo deste artigo é apresentar a análise, o problema, a solução, mas, em particular, o conceito de verdade formulado por Franz Brentano, em 1889. Como base textual, eu analiso a comunicaçáo de Brentano apresentada à comunidade filosófica de Viena, em março de 1889, intitulada Sobre o conceito de verdade (Über den Begriff der Wahrheit), e faço uma exposição sistemática da análise de Brentano acerca dos problemas que envolvem a interpretação do conceito aristotélico de verdade como correspondência. Minha interpretação explicita o modo como Brentano reinterpretou o conceito aristotélico de verdade como correspondência, no contexto da estrutura conceitual de sua psicologia descritiva.

Palavras-Chave: Franz Brentano. Intencionalidade. Verdade. Correspondência. Psicologia Descritiva.

\section{REFERENCES}

BRENTANO, F. Psychologie vom empirisch Standpunkt. Erster Band. Hamburg: Feliz Meiner, 1973.

. Wahrheit und Evidenz. Hamburg: Feliz Meiner, 1974.

. On the several senses of being in Aristotle. Tradução de R. George. Berkeley: University of California Press, 1975.

. Deskriptive Psychologie. Hamburg: Feliz Meiner, 1982.

. Descriptive psychology. Tradução de B. Müller. New York: Routledge, 1995.

. Psychology from an empirical standpoint. Traduçáo de A. C. Rancurello, D. B. Terrell e L. L. McAlister. London, New York: Taylor \& Francis e-Library, 2009a.

. The true and the evident. Traduçáo de R. M. Chisholm, I. Politzer e K. R. Fischer. London: Taylor \& Francis e-Library, 2009b.

. Von der mannigfachen Bedeutung des Seienden nach Aristoteles. Band 4. Berlin, Boston: De Gruyter, 2014.

BRITO, E. O. A descrição da atividade intencional da consciência na obra psicologia descritiva de Franz Brentano. Kinesis, Marília, v. 4, n.7, p.174-187, 2012 a. Disponível em: <http://www.marilia.unesp.br/Home/RevistasEletronicas/Kinesis/ evandrobrito174-187.pdf>. Acesso em: 16 out. 2015.

Franz Brentano e a descrição dos atos psíquicos intencionais: uma exposição esquemática do manuscrito Psychognosie de 1890. Ágora Filosófica, Recife, v.I, n.1, p.87114, 2012b. Disponível em: <http://www.unicap.br/ojs-2.3.4/index.php/agora/article/ view/164/150>. Acesso em: 18 out. 2015.

. Franz Brentano, correspondência e verdade: uma exposição esquemática da análise de Franz Brentano apresentada no texto Über den Begriff der Wahrheit (1889). Revista Guairacá, Guarapuáva, v.28, n.1, p.1-20, 2012c. Disponível em: <http://revistas. unicentro.br/index.php/guaiaraca/index>. Acesso em: 20 set. 2015. 
Psicologia e ética: o desenvolvimento da filosofia do psíquico de Franz Brentano. Curitiba: Editora CRV, 2013.

CHISHOLM, R. M. Brentano on descriptive psychology and the intentional. In: LEE, E.; MANDLEBAUM, M. (Ed.). Phenomenology and existentialism. Baltimore: The Johns Hopkins Press, 1969. p. 1-24.

. Brentano and intrinsic value. Cambridge: Cambridge University Press, 1986.

FRÉCHETTE, G. Brentano's thesis (revisited). In. FISETTE, D.; FRÉCHETTE, G. (Org.). Themes from Brentano. Amsterdan; New York: Rodopi, 2013. p. 91-120.

PORTA, M. A. G. Franz Brentano: equivocidad del ser y objeto intencional. Kriterion: Revista de Filosofia, Belo Horizonte, v. 43, n.105, p. 97-118, 2002.

Recebido: 2016-10-29

Aceito: 2017-04-19 
BRITO, E. O. 